\title{
GRIT SIZE PREFERENCES AND CONFIRMATION OF INGESTED LEAD PELLETS IN CHUKARS (ALECTORIS CHUKAR)
}

\author{
Randy T. Larsen ${ }^{1,4}$, Jerran T. Flinders ${ }^{1}$, Dean L. Mitchell ${ }^{2}$, and Ernest R. Perkins ${ }^{3}$
}

Key words: lead, Chukar, Alectoris chukar, shot, pellets, ingestion.

Lead shot ingestion has been well documented in waterfowl (Tsuji et al. 1998), raptors (Mateo et al. 2003), and Mourning Doves (Zenaida macroura; Lewis and Legler 1968). Ingestion of lead shot by upland game birds other than doves is not as well documented, but a growing body of literature suggests it does occur and can be a source of mortality (Keymer and Stebbings 1987, Lewis and Schweitzer 2000).

Walter and Reese (2003) found ingested lead pellets in $7.1 \%$ of 140 crops and $5.7 \%$ of 123 gizzards from Chukars (Alectoris chukar) in Oregon, the first known discovery of ingested lead pellets in Chukars, but cautioned that their results were site specific and that the possibility of lead pellet ingestion by other populations of Chukars should be investigated. Our objectives were (1) to determine if and to what extent lead shot ingestion by Chukars occurs in Utah and (2) to compare the size of grit collected from gizzards with common shot sizes to increase understanding of potential risks to Chukars.

Hunters were solicited, both prior to the season and when encountered in the field, to save gizzards and crops from Chukars legally harvested in Utah during the fall seasons of 2003 and 2004. Additional Chukars were collected with shotguns during both summers as part of an ongoing dietary study. Birds were collected in June-January during the study years. Crops and gizzards were placed in plastic bags, labeled (location and date), and frozen until analysis. Both crops and gizzards were carefully examined for entry wounds to distinguish between ingested lead pellets and those embedded from shot wounds (Walter and Reese
2003). Organs showing evidence of penetration wounds were not included in the analysis. Crop contents were sorted into component parts; and gizzard contents were washed (to facilitate removal of animal and vegetable matter), dried, and sifted over graduated soil sieves with perforations 3.96, 2.00, 1.68, 1.00, and $0.50 \mathrm{~mm}$ in diameter. Gizzard contents arrested at each sieve graduation were weighed to the nearest $0.1 \mathrm{~g}$ and the results combined for all gizzards.

Ingested pellets discovered during analysis were weighed on an electronic scale to the nearest $0.0001 \mathrm{~g}$ and average diameter measurements (2 directions) were calculated after measurement with calipers to the nearest 0.1 $\mathrm{mm}$. These measurements were then compared to data adapted from the 2005 Federal Ballistics Catalog (www.federalcartridge.com) to estimate the original size of each ingested pellet.

We considered 106 crops and 75 gizzards acceptable for analysis and found a single ingested lead pellet in 2 crops (1.9\%) and 8 gizzards (10.7\%). Chukars collected from 4 different counties had ingested lead pellets (Table 1). Birds with ingested pellets were harvested as early as August and as late as January with discovery of lead occurring from birds harvested in both years. Nine of 10 pellets were estimated to be size 6 or 7.5 based on weight and diameter; 1 pellet was estimated to be a size 5 . Nearly one-third of sieved grit arrested at the $2.00 \mathrm{~mm}$ sieve-as would all of the major shot sizes, with the exception of some turkeyshot and buckshot loads (Table 2). Almost 100\% of all ingested grit met or exceeded the 1.00-mmdiameter threshold positively correlated with ingestion of lead pellets in waterfowl (Mateo et al. 2000).

\footnotetext{
${ }^{1}$ Department of Plant and Animal Sciences, 275 WIDB, Brigham Young University, Provo, UT 84602.

${ }^{2}$ Upland Game Coordinator, Utah Division of Wildlife Resources, Box 146301, Salt Lake City, UT 84114.

${ }^{3}$ Upland Game Advisory Committee, 3087 Maxine Drive, Layton, UT 84040.

${ }^{4}$ E-mail: randy_larsen@byu.edu
} 
TABLE 1. Number of Utah Chukars with ingested lead pellets in gizzards and crops by county.

\begin{tabular}{lcccc}
\hline County & $\begin{array}{c}\text { Gizzards } \\
\text { examined }\end{array}$ & $\begin{array}{c}\text { Gizzards with } \\
\text { lead pellets }\end{array}$ & $\begin{array}{c}\text { Crops } \\
\text { examined }\end{array}$ & $\begin{array}{c}\text { Crops with } \\
\text { lead pellets }\end{array}$ \\
\hline Box Elder & 46 & 5 & 27 & 0 \\
Juab & 17 & 3 & 31 & 0 \\
Tooele & 9 & 0 & 22 & 1 \\
Utah & 1 & 0 & 17 & 1 \\
Unknown & 2 & 0 & 9 & 0 \\
TotaL & 75 & $8(10.7 \%)$ & 106 & $2(1.9 \%)$ \\
\hline
\end{tabular}

TABLE 2. Fractionation of sieved grit from Chukar gizzards and equivalent shot sizes.

\begin{tabular}{cccc}
\hline D Diameter $(\mathrm{mm})$ & Grit $(\mathrm{g})$ & Percentage & Shot equivalent $^{\mathrm{a}}$ \\
\hline 3.96 & 0.1 & 0.00 & Buck, T, BBB, BB \\
2.00 & 87.1 & 0.32 & $2,3,4,5,6,7,7.5,8,8.5,9$ \\
1.68 & 90.1 & 0.33 & - \\
1.00 & 98.8 & 0.36 & - \\
0.50 & 0.4 & 0.00 & - \\
\hline
\end{tabular}

aEstimated from the 2005 Federal Ballistics Catalog (www.federalcartridge.com).

Ingestion of lead pellets by Chukars was not reported in early (pre-1980) research on Chukars in North America despite several studies (Zembal 1977, Knight et al. 1979, and others), which evaluated dietary preferences from crop contents. Our results, coupled with results from eastern Oregon, mark the discovery of ingested lead pellets by 2 of the 3 most recent diet studies (Walter and Reese 2003, Churchwell and Ratti 2004), and raise concerns about general accumulation of lead pellets during the last 20 years.

Walter and Reese (2003) attributed ingestion of lead pellets to the rocky nature of Chukar habitat and heavy hunting pressure in their study area. Chukars are known to utilize rocky areas (Lindbloom 1998, Walter 2000), and pellet settlement rates are reduced on firmer soils (Schranck and Dollahon 1975). Our results are symptomatic of a regional problem more consistent with habitat characteristics and general accumulation of lead shot rather than localized hunting pressure, because ingested lead pellets were found from birds harvested in 4 different counties on several different mountain ranges. Furthermore, ingested pellets were found in Chukars collected in August, before hunting seasons commenced. This observation suggests that pellets from previous years were available, although no determinations of specific ingestion dates were made.
Unfarmed arid rangelands, such as comprise much of the western United States, may have a greater risk of lead pellets remaining near the surface than more mesic areas due to lack of tillage, relatively slow soil formation, and reduced precipitation. Tillage, for example, dramatically reduces the number of lead pellets per hectare available for ingestion (Thomas et al. 2001).

Additionally, birds such as Chukars that frequent both artificial and man-made water sources may be exposed to areas with higher concentrations of lead pellets. Stock tanks in New Mexico are reported to have higher lead densities in the surrounding soil than other heavily hunted areas across the United States (Best et al. 1992, Kendall et al. 1996). Water sources throughout the west are frequently shot over during the Mourning Dove hunt. We did find lead pellets in Chukars collected during the summer's end and early fall when use of water sources by Chukars is high. Nonetheless, birds with ingested lead pellets were also collected during December and January. Pellet retention times within the digestive tract vary from hours to several weeks (McConnell 1968) depending on diet, physiology, chance events, condition of the shot, and other factors (Kendall et al. 1996). In Japanese Quail (Coturnix coturnix), decreased pellet size in lead shot has been noted after 4 days, with complete 
dissolution of lead pellets as early as 22 days (Yamamoto et al. 1993).

We were unable to locate published research concerning the toxicity of lead pellets to Chukars, but results with ducks (Chasko et al. 1984), Brown-headed Cowbirds (Molothrus ater) (Vyas et al. 2001), and Mourning Doves (Buerger et al. 1986) indicate that even 1 retained pellet can be lethal. Multiple lead pellets are often lethal when ingested by Gray Partridge (Perdix perdix; Keymer and Stebbings 1987), Willow Ptarmigan (Lagopus lagopus; Fimreite 1984, Gjerstad and Hanssen 1984), and Bobwhite (Colinus virginianus; Damron and Wilson 1975). Sublethal effects from ingestion of 1 or multiple pellets are an additional concern well documented in other species (Kendall et al 1996, Scheuhammer and Norris 1996).

These results provide compelling evidence of lead shot ingestion by Chukars across a wide region and suggest that earlier results with Chukars (Walter and Reese 2003) are not site specific. Nearly one-third of grit ingested by Chukars corresponds to a size equivalent of all major shot sizes, a finding that emphasizes the risk for this species. More research is needed to evaluate (1) the prevalence of ingested lead pellets in Chukars throughout their range, (2) the toxicity of lead to Chukars, (3) the incidence of occurrence and toxicity in sympatric avian taxa, and (4) the influence of habitat characteristics on lead pellet availability. Unfortunately, problems associated with lead pellet ingestion seem to worsen with weathering of pellets because shot erosion within the gizzard is accelerated for weathered pellets compared to new shot (Vyas et al. 2001). Ultimately, problems with lead pellet ingestion will only be avoided by requiring the use of nontoxic alternatives.

We thank participating hunters, particularly members of the Utah Chukar and Wildlife Foundation and the Upland Game Advisory Committee. The Department of Integrative Biology at Brigham Young University provided much-appreciated research and laboratory facilities. Travis Proctor is especially thanked for his help.

\section{Literature Cited}

Best, T.L., T.E. Garrison, And C.G. SChmitt. 1992. Availability and ingestion of lead shot by Mourning Doves
(Zenaida macroura) in southeastern New Mexico. Southwestern Naturalist 37:287-292.

Buerger, T.T., R.E. Mirarchi, and M.E. Lisano. 1986. Effects of lead shot ingestion on captive Mourning Dove survivability and reproduction. Journal of Wildlife Management 50:1-8.

Chasko, G.G., T.R. Hoenn, and P. Howell-Heller. 1984. Toxicity of lead shot to wild Black Ducks and Mallards fed natural foods. Bulletin of Environmental Contamination and Toxicology 32:417-428.

Churchwell, R., and J.T. RatTi. 2004. Comparison of fall and winter food habits for sympatric Chukar and Gray Partridge in Hells Canyon of Idaho and Oregon. Northwest Science 78:42-47.

Damron, B.L., AND H.R. Wilson. 1975. Lead toxicity of Bobwhite Quail. Bulletin of Environmental Contamination and Toxicology 14:489-496.

Fimreite, N. 1984. Effects of lead shot ingestion in Willow Grouse. Bulletin of Environmental Contamination and Toxicology 33:121-126.

GJerstad, K.O., and I. Hanssen. 1984. Experimental lead poisoning in Willow Ptarmigan (Lagopus lagopus). Journal of Wildlife Management 48:1018-1022.

Kendall, R.J., T.E. Lacher, JR., C. Bunck, B. Daniel, C. Driver, C.E. Grue, F. Leighton, et AL. 1996. An ecological risk assessment of lead shot exposure in non-waterfowl avian species: upland game birds and raptors. Environmental Toxicology and Chemistry 15:4-20.

Keymer, I.F., AND R.S.J. StebBings. 1987. Lead poisoning in a partridge (Perdix perdix) after ingestion of gunshot. Veterinary Record 120:276-277.

Knight, R.L., D.A. Every, And A.W. Erickson. 1979. Seasonal food habits of four game bird species in Okanogan County, Washington. Murrelet 60:58-66.

LEWIS, J.C., AND E. LEGLER, JR. 1968. Lead shot ingestion by Mourning Doves and incidence in soil. Journal of Wildlife Management 32:476-482.

LEWIS, L.A., AND S.H. SCHWEITZER. 2000. Lead poisoning in a Northern Bobwhite in Georgia. Journal of Wildlife Diseases 36:180-183.

LindbloOm, A.J. 1998. Habitat use, reproduction, movements, and survival of chukar partridge in west-central Idaho. Master's thesis, University of Idaho, Moscow.

Mateo, R., R. Guitart, and A.J. Green. 2000. Determinants of lead shot, rice, and grit ingestion in ducks and coots. Journal of Wildlife Management 64:939-947.

Mateo, R., M. Taggart, and A.A. Meharg. 2003. Lead and arsenic in bones of birds of prey from Spain. Environmental Pollution 126:107-114.

McConnell, C.A. 1968. Experimental lead poisoning of bobwhite quail and Mourning Doves. Proceedings Annual Conference Southeast Association of Game and Fish Commissioners 21:208-219.

Scheuhammer, A.M., And S.L. NorRis. 1996. The ecotoxicology of lead shot and lead fishing weights. Ecotoxicology 5:279-295.

Schranck, B.W., and G.R. Dollahon. 1975. Lead shot incidence on a New Mexico public hunting area. Wildlife Society Bulletin 3:157-161.

Thomas, C.M., J.G. Mensik, and C.L. Feldheim. 2001. Effects of tillage on lead shot distribution in wetland sediments. Journal of Wildlife Management 65:40-46.

TsujI, L.J.S., J. YounG, AND D.R. KozLovic. 1998. Lead shot ingestion in several species of birds in the western 
James Bay region of northern Ontario. Canadian Field-Naturalist 112:86-89.

Vyas, N.B., J.W. Spann, AND G.H. Heinz. 2001. Lead shot toxicity to passerines. Environmental Pollution 111: $135-138$.

Walter, H. 2000. Ecology of the Chukar in eastern Oregon. Master's thesis, University of Idaho, Moscow.

Walter, H., AND K.P. ReEse. 2003. Fall diet of Chukars (Alectoris chukar) in eastern Oregon and discovery of ingested lead pellets. Western North American Naturalist 63:402-405.

Yamamoto, K., M. Hayashi, M. Yoshimura, H. Hayashi, A. HiRatsuKa, AND Y. IsII. 1993. The prevalence and retention of lead pellets in Japanese Quail. Archives of Environmental Contamination and Toxicology 24: 478-482.

Zembal, R.L. 1977. The feeding habits of the chukar partridge (Alectoris chukar) in the Argus and Coso Mountains of California. Master's thesis, California State University, Long Beach.

Received 29 October 2005 Accepted 31 May 2006 